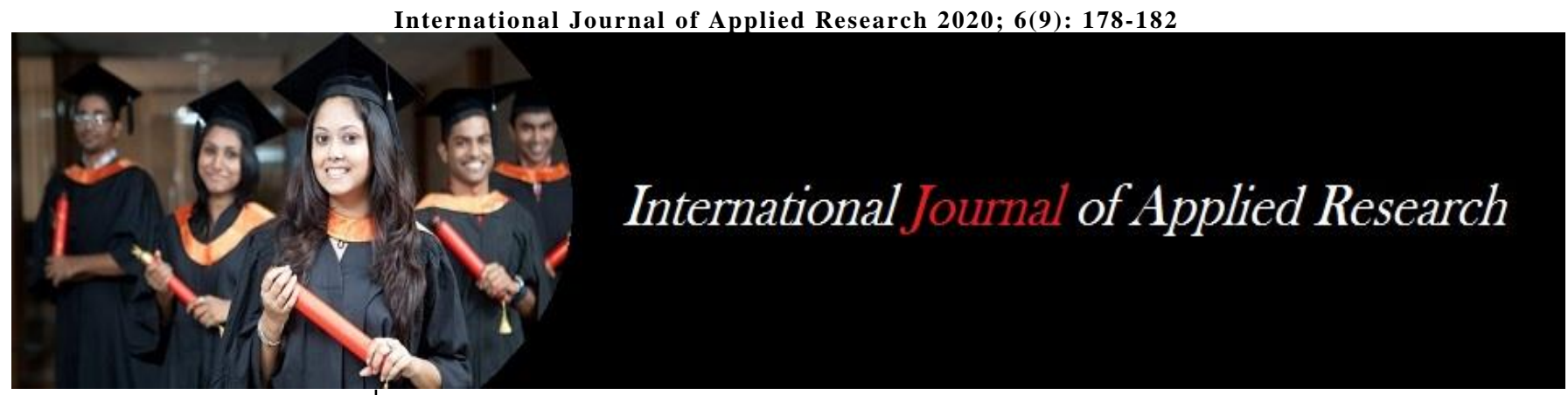

ISSN Print: 2394-7500 ISSN Online: 2394-5869 Impact Factor: 5.2 IJAR 2020; 6(9): 178-182 www.allresearchjournal.com

Received: 18-06-2020 Accepted: 10-08-2020

Chow Chandra Mantche Associate Professor, Department of History, North Lakhimpur College Autonomous, Khelmati, Assam, India
Corresponding Author: Chow Chandra Mantche Associate Professor, Department of History, North Lakhimpur College Autonomous, Khelmati, Assam, India

\section{Some aspects of the pre-Buddhistic practices among the Tai-Khamtis of north-east India}

\section{Chow Chandra Mantche}

DOI: $\underline{\text { https://doi.org/10.22271/allresearch.2020.v6.19c.7117 }}$

\section{Abstract}

The Tai-Khamtis, a branch of the Shan Tai race, immigrated from Moung Khamti Long or Bor-Khamti of Upper Burma in the last part of $18^{\text {th }}$ century is one of the enterprising tribes of north-east India. The Tai-Khamtis contributed a lot to the history and culture of the region. They played a significant role in the frontier history of India's extreme north-eastern region and the resistance they offered to the colonial regime marked them out for special attention in the administrative history of the area. Although, they follow Theravada form of Buddhism, some sort of pre-Buddhistic rituals and practices are noticed in their day to day life which forms an intrinsic part of their socio-cultural life. The study of their rituals and practices reveal that their religion has absorbed some traits of pre-Buddhistic SouthEast Asian cultural traditions which they had brought with them at the time of their migration. The study is significant to understand India's cultural relations with the south-East Asian countries.

Keywords: North-east India, Tai-Khamtis, Theravada, Pre-Buddhistic practices

\section{Introduction}

The Tai-Khamtis are the largest Theravada Buddhist tribe of north-east India. In the state of Arunachal Pradesh, they are living in the district of Namsai, Changlang and Lohit respectively and their total population is estimated to 12,653. In the state of Assam, the TaiKhamtis are one of the microscopic minority tribes having less than five hundred of their population distributed in six villages namely Narayanpur (Bor-Khamti), Sribhuyan, Gosaibari, Borpather, Deotola and Tipling respectively under Nrayanpur Revenue Circle of Lakhimpur district.

As far as the religion of the Tai-Khamtis is concerned, they are followers of Theravada form of Buddhism after the Burmese tradition. However, some sort of pre-Buddhistic and sometimes may be called anti-Buddhistic practices are noticed in their socio-religious traditions. Way back in $1873 \mathrm{CE}$, British traveler T.T. Cooper observed that "in religion they affect to be strict followers of Burmese Buddhism, but, excepting among the priests, their religion is little more than polytheism under a thin veil of Buddhist pantheism, the beauty of Gautama's teaching being utterly unknown amongst them, while many of their customs are altogether opposed to Buddhism ${ }^{[1]}$. Although they describe their religion as Theravada, there are some traits of Mahayana creed and Trantikism as well as Brahmanical religion as is evinced by the numerous images of Buddhisattvas, Nagaraja, Vasumati or earth goddess etc. The life pattern of the people also suggests that the original form of their Theravada has absorbed some traits of other cults like Mahayana, Ari or demon worship and Brahmanism that prevailed in Burma ${ }^{[2]}$.

\section{Objectives of the study}

The main focus of our attention in this paper is to draw an outline of the pre-Buddhistic customary practices of the Tai-Khamtis of north-east India. The present paper tries to focus on the significance of the pre-Buddhistic practices in their day to day life. The study also reflects the influence of the neighbouring tribes and impact of South-East Asian culture on the life and culture of the Tai-Khamtis. 


\section{Methodology}

Descriptive historical and analytical methodologies have been used for the study. Both primary and secondary sources are utilized in the paper. Primary data are collected through personal interviews and experiences gathered during the course of field study. Interviews of the priest and learned men of the tribe have been taken into consideration to supplement the published materials. The secondary data in form of books, journals, research articles, Census report, Govt. Gazetteers are consulted to support the qualitative data.

\section{Discussion}

Many of the tribes of north-east India believe in numerous categories of spirits. They believe that every kind of action and effect has got positive and negative values. It is believed that for each kind of action, a particular spirit is responsible. Although the Tai-Khamtis professed Theravada form of Buddhism, some pre-Buddhistic practices like spirit/demon (phi) worship are prevalent in their religious traditions as well as in their merit making occasions. They believe in the existence of different spirits called phis (spirit/demon) which directly or indirectly influenced in the journey of life. A brief description of spirit worships is presented for better understanding the pre-Buddhistic belief and practices prevail in their society.

\section{Phang-suo-moung}

Phang-suo-moung is one of the important phi worship among the Tai-Khamtis. The worship for the reconciliation of the protecting deity of the country is called phang-suomoung. It is observed for well being of the village and for protection from ferocious animals. It is also observed during crop failure, epidemic and bad weather. In general, it is worshiped beneath a tree adjoining agricultural field of the village. All family members of the village except women participated in the worship. Symbolic huts for the deity are made with the help of banana plunk at the place of worship. Incense sticks and candles are lit. People offered cooked food, vegetables, fruits, puffed rice, sweets, flowers to the deity of the village (phi-maan) and the deity of country ( $p h i$ moung) respectively. Congregational prayer followed by appropriate chants to propitiate the deity is held which aimed to bring well being of the village for the ensuing year. No sacrifice is done in this worship. At the end of the worship, feast is held. If a cow is seen during the worship, good harvest is expected for the year. In the entire process of the worship, the Buddhist monk don't participate and it is performed under the priesthood of the village called "chaomo or pathek". Normally, Tai-Khamtis performed this worship in the fifth (nun-ha=April-May) or the sixth (nunhuk= May-June) month of their indigenous calendar. The date of the worship is selected in an auspicious day after the poi Changken (A spring festival corresponding to Rongali Bihu of Assam).

In the past, the Khamtis sacrificed animals to propitiate the spirits of the village. In the honour of phi-muang, animals are sacrificed once in the year. B.J. Terweil has provided an interesting note on Phang sau moung rituals held in the third decade of nineteen century in the village of BorKhamti(Narayanpur) in which animals are slaughtered to propitiate the spirit of the village. The festival held in a convenient day of the year preferably in the month of April. It is reported that the festival began one afternoon and lasted throughout the following night until day light the next morning. On the day of the ritual, outsiders are not permitted to enter the village. The Khamtis had a sacrificial tradition and that these customs have all been discontinued. Each village abandoned its large-scale communal sacrifice at its own time. This constitutes an interesting fact which is indicative of increasing of Buddhism vis a vis these aspects of Tai customs which appear to belong to pre-Buddhist beliefs and practices ${ }^{[3]}$. The Tai Ahoms performed this worship as Me-Dam Me-Phi collectively in different villages. The Tai Khamtis of Narayanpur regularly held $M e$ Nam Me Phi (Nam=dam=ancestor) near the "Nong hao phi" tank situated near Bor-Khamti village accompanying with sacrifice of buffalo, pig and drinking rice beer and meat. According to local people it was held upto about 1928 A.D. It is said that there was no Buddhist monk among the Tai Khamtis of Narayanpur. But later on, with the coming of the Buddhist monks from Myanmar, the villagers had abandoned the worship of Me-dam me-phi ${ }^{[4]}$.

\section{Phi-nam- huan (pai nahong pai chan)}

The Tai Khamtis believe in the family and clan spirit. They usually propitiate the spirit of the deceased parents or grandparents known as "phi- huan". They also propitiated the spirit of their founder clan called "phi-nam-huan or phi nahong-pai chan". They have a great reverence to the spirit of their ancestors. It is believed that the ancestors desire propitiation with offerings from their living progenies and dissatisfied ancestors may caused sufferings to the family members. According to their traditional believes, the spirit of their ancestors resides in the north-eastern corner pole (sao lai) and the south-eastern corner pole (sao nam) of their house. The female spirit (very furious, as they believe) resides in the north-eastern pole while the male spirit resides in the south- eastern corner pole in their respective houses. Therefore, these two poles (sao-phi-nams) are considered auspicious and the adjoining places of the poles are always kept neat and clean. As a mark of respect, they offer cooked food, puffed rice, flowers and pour water in every meritorious works of their family. Dirty clothes, vests, mops, brooms, cooking materials, fishing implements etc. are always keep away from these two poles. In every meritorious functions of the family, the spirits of ancestors are worshipped among them. During the festive occasions, the worship of phi-nam-huan is a mandatory work. Normally, the worship of the phi-nam-huan is performed before noon preferably before breakfast. To worship the spirit, two small pyramids (about two feet high) make out of sand known as "kongmu" are made beside the two poles (sao-nams). A kongmu is a circular conical shaped heap of sand tapering to a point which is decorated with tankhan, caaku and flowers. The tankhon is a special small flag made of thin bamboo stick, end of which is bent over and held into place with a thin thread that carries a piece of white paper cut out in a distinctive pattern possibly to recognize a shape of a human body. The tankhon is coupled with another stick called caaku which carries a small paper flag as well as a numbers of paper shreds which have been attached to the top. The head of the family lit candle, incense sticks in front of the kongmu and offered cooked foods, fruits, sweets, puffed rice, flowers and water to the spirit and prays for the well beings of the family. At the end of the offerings, water libation is held. In the pristine, the Khamtis kill their domestic animals in order to honour the 
house spirits, phi-huan. The flesh of the sacrificed animals was cooked and eaten by all family members. Offerings are normally accompanied by appropriate chanted verses which are aimed to arouse joyful and devout contemplation for spiritual progress. It is said the conventionally ascribed stereological benefits of the offering flowers for health and beauty, water is a means to a cool mind, peaceful and free from worry, food assures adequate nourishment, the lighted candles are a means to enlightenment and glory ${ }^{[5]}$. The worship of the kongmu of sao phi nam of the north-eastern corner is followed by the kongmu of the southeastern corner. In general, the worship of the phi-nam-huan is held during the harvesting season. The Tai Khamtis never use their new seasoned rice (harvest-feast) prior to the offering of their respective phi-nam-huan and Buddhist monks.

\section{Hong-khwan ceremony}

The spirit calling ceremony among the Tai Khamtis is known as hong khawn ceremony. It is one of the most prominent pre-Buddhist religious ceremonies observed to regain the lost soul or spirit of an ailing person or weak soul for longer sickness. The conception of essence of soul is widely distributed among different ethnic groups of Asian countries and it is an old Tai belief [6]. Literally "hong" means to bring back and "khwan" means spirit, essence of life or soul. The Khamti and other Tais called the spirit calling ceremony as hong khwan or hik khwan. The Ahoms call it Rik khwan or rik khwan mung khwan ${ }^{[7]}$. In Assamese version it is known as "Ayutula or Ayuana", which means the bringing back the essence of life. The concept of khwan is very obscure. A Buddhist monk may feel that the nearest Pali equivalent is "Vinnana" (principle of conscious life). Other may think of 'soul' or 'spirit', but none of these descriptions provides a satisfactory translation of khon. Assamese and English do not seem to have an equivalent term, a fact often encountered with abstract concepts ${ }^{[8]}$.

In case, a man or an woman who fell sudden sick after a deep shock or afraid, the Khamtis think that good soul of the person is being taken out by some spirit and evil spirit occupy the former place. According to their traditional belief, the body and mind of a human being is governed by the "khwans" which are stored in the human body and when the quantity of khwan is lost or decreased, the human body is attacked by diseases. Similarly, when a person is terrified or he falls in water or falls from any up, then the volume or quality of khwan is lost. The body and mind become inactive. In such situation, Hong khwan ritual is performed. When a person falls in serious illness, the Khamtis think that good soul of the person is being taken out by some spirit and evil spirit occupy the former place. Therefore, in case of serious illness, they conduct worship by keeping sword, gun and egg near the sick person and some elderly members read from the punthi (sacred book) and therapeutic ritual is performed.

The Tai Khamtis believe that a khwan is an element of vitality, vigor and strength of a person. The ceremony to bring back the khwan is called 'son khwan' which is normally arrange in dusk. They believe that a khwan may flee into deep water and so the khwan is floated with fishing implement called "khyek". To lift khwan, as an omen of good luck, they look for a lizard or a fish. All the material lifted with help of khyek are wrapped in a cloth and placed in front of the ancestral pole of respective house which is called sao- phi-nam and the therapeutic ceremony is performed.

Like an individual human being, they believe that the country also has its khawn. Sometimes, the khawn of the country also needs orientation. When the country is attacked or facing abnormal situation, a ceremony called "Hong khwan moung khwan" is performed to provoke the God to augment the power of khwan for the country. Sometimes, royalty used to recognize khwan with royal grandeur after battle they fought, with a view to get release from sin, they committed by killing men in the battle or to win in the battle by strengthening khwan. This ritual is performed with royal grandeur, all the household articles like bows, arrows, knives, daoes(chopper), spades, battle axe, swords, spears etc. are enameled and fruits, sweets, foods are offered to the ancestral spirit. The basic difference between the "son khwan" and "hong khwan" is that "hong khwan" is basically aggressive, the ritual specialist is in command and orders the tools and weapons to bring back the "khwan", on the other hand "son khwan" is characterized by pleading and cajoling. The two therapeutic rituals son khwan and hong khwan demonstrate how a stray element of vitality can be induced to return to the human body ${ }^{[9]}$.

The Tai-Khamtis have great respect for nature and wherever they found any power or beauty, they entreat mercy from the object and invested them with supernatural character. They believe that the supernatural power direct and control human life. They believe in extra sensory super powers and to them material objects are as animated as themselves and an invisible spirit presides in themselves, and in other objects and beings. That's why, they propitiate or conciliate these super natural powers, which they believe, direct and control human life ${ }^{[10]}$.

So, for reconciliation the super natural powers they worship them in forms of spirits or phis. According to their needs and requirements they worship various types of spirit like spirit of paddy field "phi-na", the spirit of forest "phithoun", the spirit of water "phi-nam", the spirit of hill "phinoi" the spirit of country "phi-moung", the spirit of house "phi-huan", the spirit of the village "phi-maan" etc. They pay great reverence to the spirit of their village. The existence of a special hut dedicated to the spirit "phi-maan" is a common feature of a traditional Khamti village. A small monument is constructed in the name of the "phi-maan" at the entrance of the village. This symbolic monument or hut is known as "ho-phi") ${ }^{[11]}$. They have their own village God locally called Kaliabapu. The sacred place is located at the end of the residential huts in the north-east of the village. Twice in every year, the villagers worship this deity. The family members just offer the foodstuff to the deity. The villagers have constructed one small shelter for this deity. The villagers consider this deity as very powerful ${ }^{[12]}$. In Tai-Khamtis society, the spirits are propitiated according to occasional demands, for instance when a person returning from the forest falls ill, it is believed that the forest spirit is offended. So, phi-thoun is propitiated by offering flowers and candle near the forest ${ }^{[13]}$.

In addition to the worship of various spirits the Tai Khamtis worship some Gods and Goddesses on various occasions. A brief account of these worships is presented below.

Kantu-nang or Pai-nang: (Kantu / Pai=bow down, pay reverence, Nang= Lakhsmi/ Devi) 


\section{Aao khon khao}

The Tai-Khamtis worship the Goddess of fortune Lakhsmi which is known as Kantu nang or Pai nang. They worship the goddess after entire paddy is thrust. They make an elaborate preparation to satisfy the goddess. The day when the paddy is to be brought to the house, the women of the family clear the place in the field where the paddy has been thrust. Khao-no (a kind of sticky rice), mokwan (sweets), khaai (egg), kowi (banana), oi (sugarcane) are to be kept in a vessel near the paddy. The powdered rice is spread in the boundary of one's paddy field and also around the paddy stocked in the field. This is to be done by the head of the family. Then the head of the family reads the sloka from punthi. In the house, within the granary (ye-khao) one bucket, full of paddy is kept on which two eggs are kept which symbolize the existence of khwan and germination. Then the paddy is brought inside the granary and head women recite sloka from the sacred book. The free translation of which is - you have come now at my granary and please be here for years to come. Though we would take out paddy time to time from the granary, but like the unlimited water of river, I believe, it would never be empty. You, as the Lakhsmi of paddy be at my granary. I will worship you for time immemorial ${ }^{[14]}$. Similar practice of calling of the khwan of rice is prevalent in Thailand also. The calling of the spirit of rice in Thailand is called sukhwan khaw ${ }^{[15]}$.

Kantu-nang or Pai-nang: (Kantu or Pai=bow down, pay reverence, $N a n g=$ Devi)

The Tai Khamti performed kantu-nang ritual when someone is suffering from pox (oak-nang). In this ritual (kantu-nang), three or five women are required. In general, they wear white dresses at the time of worship. They prepare porridge to propitiate the Goddess. After lightening candle and incense sticks, they offer porridge, banana, white flower, one egg, betel nut, betel leaf and a token money and pray to the goddess nang (Assamese appellation Sitala Devi). Sometimes, the egg is broken and smeared in the body of the sick person. At the end of the worship, they tie a white thread in the wrist of the sick person and offer blessing for his/her quick recovery. This ritual is worshipped with utmost neat and clean to satisfy the Goddess (Nang). They believe that if the Goddess is not satisfied some bad effect will remain in the body and mind of the affected person. Therefore, this ritual is performed with utmost care.

Tong- kani- pan: (tong=offer, kani=opium, pan = betel leaf) The Tai Khamtis offer kani pan when their live stocks are suffering from some sort of diseases. The male members participate in this ritual. A special temporary shed is made in front of their cowshed to perform the ritual. They offer porridge, opium, hemp, sweets, betel nut, and betel leaf, a token money, candle and incense sticks to satisfy the deity. The opium smokers are the main priest in this ritual. After the completion of the worship in proper manner, all the food items are consumed by the worshipers. The use of hemp, the essence of the chanted verses and prayers, involvement of the non-Khamti devotees in the ritual indicate occasional worship of the Hindu deity Mahadeva is also prevalent in their society in a considerable low degree.

Ye-nam (water libation ceremony)
In every religious and auspicious occasion, the Tai-Khamtis perform water libation (ye-nam) rite which seems preBuddhistic in nature. No any meritorious occasion is completed without the water libation rite. While water is poured drop by drop from yang-le(water pot)into a vase and thence on to the ground, the congregation recites, we have offered candles, flowers and alms food (simi, mokya, khaosom) to Buddha, we have observed the precepts (sin-ha). May the deva and Nang Vasung-Tuli (Pali, Vasundhara) bear witness to our meritorious work. May I, as a result of this merit, attain Nibbana. This water-libation ceremony, as then Khamtis called it, is an intrinsic part of all ceremonies and public acts of meritorious giving's. As the formula indicates it calls merit of worshippers to the attention of an earth goddess known in Khamti Buddhism as "Nang Vasungtuli", and in ancient India Vasundhara. Although, little known in ancient Indian Buddhism, this goddess is widely known to the Buddhist of South East-Asia. Indeed, it is a myth associated with her that provides the Buddhist character for water libation ritual, which is no doubt older than Buddhism in South- East Asia ${ }^{[16]}$.

\section{Pai nang sulasati (Worship of Saraswati)}

Worship the goddess of learning Saraswati (Nang Sulasati) among the Khamtis is restricted to those who compose drama (pung). As reported during the course of field study, the composers (chao mos) worship the deity for seven days for his attainment. In the worship, altar is made; various kinds of foods are offered to the deity and after completion of worship, all the foods are consumed by the worshipers. At the beginning of the play, the dramatist cum director of the play (Chow-mo) offer prays to Sulasati (Saraswati), the Goddess of learning for any omission and commission on the part of the actors and actress in performing their role in the play. Lik Nang Sulasati (hymns of Saraswati) is also accepted as 'mohini mantra' (charm) ${ }^{[17]}$. The worship of Tai traditional manuscript charm, however, is performed outside temple or at home.

\section{Tok-ang (art of tattooing)}

The Khamtis tattoo their body which is considered to be forms of therapeutic ritual. In old days, it was done either to cure a person of some complaints or to prevent someone from contacting a disease. The elaborate tattoo, it is believed, carried a power called Luupii-Thaapii, which made the wearer of tattoos invulnerable ${ }^{[18]}$. The art of tattooing one's body is also a common practice among the Shans of Burma. It is told that tattooing on the legs is chiefly practiced as a decoration; it is a sign of manhood; no girl recognizes the fact that a youth is a marriageable age until his legs can show the blue marking. Love-charms are tattooed on the arms or on the tip of the tongue. Fine wires of gold, or small discs of gold or silver, are sometimes inserted under the skin of the arms, back, or chest. The wires are supposed to keep at a distance the evil spirits that bring sickness the discs are charms to prevent all kinds of wound ${ }^{[19]}$.

\section{Conclusion}

There are many customary practices of phis and God and Goddesses prevalent among the Tai-Khamtis. The study of their rituals and practices reveal that their religion (Theravada) has absorbed some traits of pre-Buddhistic 
South-East Asian culture which they have brought with them at the time of their migration. According to their traditional believe the spirits are benevolent as well as malevolent in nature. It is to be noted that the Buddhist monks of the village are not associated with the practices of such rituals and the rituals are not held within the campus of the monastery. In some rituals, women are not allowed to participate. The priest of the village called pathek or Chao $m o$ is the chief executive of the phi worships.

The Khamtis had a sacrificial tradition and that these customs have all been discontinued. Each village abandoned its large-scale communal sacrifice at its own time. We are told that the sacrificial tradition among the Khamtis of Narayanpur lasted till third decade of nineteen century. It is reported that some clans namely Longkeng, Longchat, Lukhans and Mancheykhun of the settlement till now visit the Barkalika than (a Devi temple where animal sacrifice is held) at Kalabari village of modern Sonitpur district of Assam. Some of the Khamtis of Naranpur even took the initiation in the Dakhinpat Satra of Majuli. The study reflects the influence of neighbouring Hindu society in some of their rituals like Kantu- nang, Tong -kani-pan and Painang-Sulasati etc. The offerings of grinded raw ricepowder, gram, porridge in the Kantu-nang rituals and use of opium and hemp in the Tong-kani-pan rituals clearly indicate the influence of neighbouring Hindu society. The influence of some Hindu customs is evinced in their traditional performing art i.e. in pya- pung (drama staging). Thus, due to influence of neighbouring Hindu community a synchronization of cult took place. At present, the sacrifices of livestock and use of rice beer which constituted the key ingredients in some of their phi worships in the past are not in vogue.

With the spread of modern education, development of science and technology, some drastic changes have been noticed in the traditional way of observing customary practices among the Tai-Khamtis. Although they practice many pre-Buddhistic rituals in their society, they are still staunch followers of the Theravada form of Buddhism. They do not consider that such beliefs and practices are affecting in their way to follow the basic tenets of Theravada form of Buddhism. It is to be noted that preBuddhistic practices are restricted to a section of the tribe; neither the monks nor the raja and elite section of the society practice such rituals. The study reveals the fact that most of their rituals traveled across the boundary at the time of their migration to the present settlement and forms an intrinsic part of their life and culture. The study is significant to provide a glimpse of cultural heritage of South-East Asia which is very important in the present day context specially to locate north-east India in the wake of India's policy of "Act East".

\section{References}

1. Cooper TT. New Routes of Commerce: An account of the journey in an attempt to penetrate Tibet from Assam to open new routes for commerce, London, 1873, 145.

2. Chatterjee, Subid. A Comprehensive History of Arunachal Pradesh, 15B Jatin Bagchi Road, Calcutta, 1991, 21.

3. Terwiel BJ. The Tai of Assam and Ancient Tai Ritual Centre for South East Asian Studies, Gaya. 1980; 1:3637.
4. Gogoi, Puspadhar. Tai of North East-India, Chumphra publication, Dhemaji, 1996, 103-104.

5. Kondinya, Monastic Buddhism among the Tai Khamtis of Arunachal Pradesh, National Publishing House, Delhi, 1986, 15.

6. Tripathy B, Dutta S. Religious History of Arunachal Pradesh, Gyan Publishing House, Delhi, 2008, 241.

7. Vide interview with Chow Kim Manchey(75), Gosaibari Village, Lakhimpur.

8. Terwiel, B.J., op. cit., Pp 57-59.

9. Ibid

10. Tripathy B, Dutta S. op.cit., p. 241.

11. Singh KS. (ed), People of India, Arunachal Pradesh, Anthropological Survey of India, Calcutta. 1995; XIV:183.

12. Sarkar, Jayanta. Society, Culture and Ecological Adaptation Among Three Tribes of Arunachal Pradesh, Anthropology Survey of India, Calcutta, 1987, 152.

13. Mishra, Neeru, Sachidananda Sahai. (ed), Indo-Thai historical and cultural linkages, Monohar, Delhi, 2007, 173.

14. Sarkar, Jayanta., op.cit, 152-153.

15. Tambiah S, Buddhism J. and the Spirit Cults in NorthEast Thailand, Cambridge, 1970, 361-366.

16. Kondinya, op. cit., 68.

17. Tripathy B, Dutta S. op. cit., 240-241.

18. Ibid.

19. Milne, Lislie. Shans at Home, John Murray, London, $1910,67$. 